\title{
Ірина Ворончук, Родоводи волинської иляхти XVI - першої половини XVII cm. (реконструкція родинних структур: методологія, методика, джерела), Київ 2009, ss. 512
}

W 2009 r. nakładem wydawnictwa „Wyższa Szkoła” (Вища школа) ukazała się w Kijowie książka Iryny Woronczuk pod tytułem, który można przetłumaczyć jako „Rodowody szlachty wołyńskiej XVI i pierwszej połowy XVII w. (rekonstrukcja rodzinnych struktur: metodologia, metodyka, źródła)”. Pojawienie się tej pracy jest szczególnie ważne dla historyków i badaczy-amatorów interesujących się szesnasto - i siedemnastowiecznym Wołyniem, a szczególnie tamtejszymi rodami szlacheckimi.

Monografia składa się ze słowa wstępnego od autora i z trzech rozdziałów: „Metodologiczne zasady rekonstrukcji rodzinnych struktur: systemy i stopnie pokrewieństwa” (s. 5-14), „Analiza aktowej dokumentacji pod kątem rekonstrukcji rodziny” (s. 15-32), ze złożonego z wielu podrozdziałów rozdziału „Aktowa terminologia rodzinna” (s. 33-134). Obszerny fragment książki obejmuje część zatytułowana „Źródła”, w której mieszczą się „Przykłady akt nasyconych rodowodowymi informacjami” (s. 138-174) oraz „Rodowodowe tablice wołyńskiej szlachty XVI - pierwszej połowy XVII w. (rekonstrukcja na podstawie wołyńskich ksiąg aktowych)" (s. 176-307). Na końcu książki znalazł się łacińsko-ukraiński słownik terminologii rodzinnej (s. 308-309), indeks geograficzny (s. 310-314) oraz rozbudowany indeks osobowy (s. 315-509).

Zasadniczą podstawą źródłową wykorzystywaną przez autorkę są wołyńskie księgi grodzkie i ziemskie (łuckie, włodzimierskie, krzemienieckie) oraz dziewięt- 
nastowieczna 34-tomowa edycja źródeł dotyczących terytorium dzisiejszej Ukrainy pt. „Archiv jugo-zapadnoj Rossii, izdavaemyj Vremennoju Kommissieju dlja Razbora Drevnich Aktov"”. Nie jest to zaznaczone wprost, ale prawdopodobnie wykorzystała również dostępne herbarze, dość obszernie omówione na stronach 106-120.

Autorka w krótkim wstępie zatytułowanym „Do Czytelnika” (s. 3-4) pisze, że idea książki narodziła się, gdy przygotowywała doktorat na temat wołyńskiego chłopstwa XVI-XVII w. Odkryła wówczas, że w ukraińskiej historiografii brak danych o wielkości zaludnienia poszczególnych województw, a dostępne dane liczbowe są przestarzałe i niepoparte materiałami statystycznymi i analizą ówczesnej sytuacji. Tak narodził się pomysł badań nad problem zaludnienia Wołynia. Analizując pod tym kątem księgi grodzkie i ziemskie zebrała bardzo wiele materiału, „który pomógł rekonstruować ówczesne rodziny szlacheckie, stworzyć statystyczny ciąg dla wyznaczenia przeciętnego współczynnika szlacheckiej rodziny i ustalić model ówczesnej rodzinnej struktury, jako społecznego organizmu”. Zakładała, że genealogiczne tablice będą dodatkiem do monografii dotyczącej ludności Wołynia XVI i pierwszej połowy XVII w. Okazało się jednak, że jest ich zbyt wiele, by wszystkie zamieścić w planowanej książce. Stąd pomysł na odrębną książkę poświęconą rodowym strukturom wołyńskiej szlachty, w której, jak pisze, wykorzystała tylko część zebranego materiału. Być może przez to do obecnej książki trafiły fragmenty tekstu i idee metodologiczne niewiążące się ściśle z zasadniczym tematem książki. Jednym z nich jest rozdział pierwszy zatytułowany „Metodologiczne zasady rekonstrukcji struktur rodzinnych. Systemy i stopnie pokrewieństwa” (s. 5-14). Autorka szeroko omawia w nim założenia zachodnich badań nad historią społeczną, nad historią rodziny i mikrohistorią. Powołuje się na prace Tamary Hareven, Johna Hajnala, Petera Lasletta (s. 5-6), następnie omawia literaturę podejmującą problematykę ukraińskiej rodziny. Badania nad tym tematem podejmowano jedynie w XIX w. i wrócono do nich dopiero w ostatnich latach. Jak wskazuje autorka - nauka radziecka nie podejmowała badań nad jednostką a nad masami, mechanicznie rozpatrując pewne standardowe tematy, głównie dotyczące ekonomicznej pozycji i walki klasowej robotników i chłopstwa. Zajmowały ją makro procesy w oparciu o socjologiczne schematy, co doprowadziło do dehumanizacji badań historycznych (s. 7-9). Dopiero

\footnotetext{
1 Архив Юго-западной России, издаваемый временной комиссией Аля разбора Аревних актов, Киев, 1859-1911.
} 
$\mathrm{w}$ ostatnich latach pojawiły się badania powiązane $\mathrm{z}$ historią lokalnych struktur, w tym rodziny, a także wyłącznie jej dotyczące (np. J. Horeszko, I. Woronczuk, N. Starczenko), głównie dotyczących ślubów szlacheckich. Podkreśla brak badań dotyczących szeroko pojętej rodziny (wiek zawarcia małżeństwa - wczesny czy późny, struktura rodziny, powiązania wewnątrz rodziny). Jednym z takich niezbadanych zagadnień jest typologia ukraińskiej rodziny, która wyznacza jej strukturę i liczebność, a których głównymi wskaźnikami są skład pokoleniowy, wiekowy i rodzinny. W tym miejscu I. Woronczuk zapomina chociażby o badaniach M. Krykuna i J. Wołoszyna².

Następnie autorka omawia „metodę rekonstrukcji rodzin” L. Henry’ego zaznaczając przy tym, że w interesującym ją okresie na prawobrzeżnej Ukrainie nie było jeszcze ksiąg metrykalnych, na których ta metoda się opiera ${ }^{3}$ (s. 11). Stąd, jak podkreśla, „zadanie rekonstrukcji konkretnych ukraińskich rodzin XVI-XVII w. potrzebowało znalezienia innych źródeł, innego dokumentalnego materiału i metodyk, na podstawie których można stworzyć pewien statystyczny ciąg zdatny do wyjaśnienia pytań, co do stereotypu masowych zachowań demograficznych i czynników, które formowały i wpływały na model ślubów, a wraz z nim na strukturę i typologię ukraińskiej rodziny XVI-XVII w. Informacje o konkretnych rodzinach i ich składzie potencjalnie mogą się znaleźć w ówczesnych źródłach masowego charakteru. To znaczy, dla wyznaczenia typologii i struktury ukraińskiej rodziny wczesnonowożytnej epoki (XVI-XVII w.) udało się skorzystać z dokumentalnych materiałów, aby na ich podstawie odtworzyć konkretne rodzinne struktury, czyli zrekonstruować poszczególne rodziny różnych warstw społecznych ówczesnego ukraińskiego społeczeństwa. Tylko odtworzywszy poszczególne rodzinne struktury, będzie można uzyskać statystyczne dane, dla modelowania przeciętnej struktury ukraińskiej rodziny, która będzie odpowiadać historycznym

2 М. Крикун, Населення домогосподарств у Житомирському повіті Київського воєводства 1791 року, Україна модерна, ч. 6. Аьвів 2001, s. 25-46; Ю.В. Волошин, Розкольницькі слободи на території Північної Гетьманщини у XVIII cm. (історико демограббічний аспект), Полтава 2005 (w książce autor bada zagadnienia demograficzne i strukturę rodziny; tam obszerna literatura ukraińska i rosyjska).

3 Metoda ta polega na odtworzeniu losów demograficznych rodzin na podstawie przyporządkowania parom małżeńskim wszystkich dotyczących ich wydarzeń demograficznych zarejestrowanych w księgach metrykalnych (m.in. zawarcie związku małżeńskiego, urodzenia i śmierć kolejnych dzieci, śmierć jednego z współmałżonków), C. Kuklo, Demografia Rzeczypospolitej przedrozbiorowej, Warszawa 2009, s. 174 i n. 
realiom” (s. 12). Te źródła masowe to dokumentacja zawarta w księgach grodzkich i ziemskich, które I. Woronczuk omawia szerzej w rozdziale drugim (s. 16).

Zasadniczym problemem tej książki jest fakt, że cytując zachodnich autorów, a zwłaszcza Petera Lasletta i Louisa Henry’ego autorka doprowadziła do pomieszania pojęć. Zresztą odwoływanie się do ich prac wobec tytułu niniejszej książki nie ma żadnego uzasadnienia. W jaki sposób I. Woronczuk badając właściwie powiązania rodzinne w rozumieniu rodowym (genealogicznym) może wykorzystać i wykorzystuje przytoczony przez nią fakt istnienia tzw. linii Hajnala, umownie określającej strefy późnych ślubów na zachodzie i wczesnych na wschodzie Europy ${ }^{4}$, zwłaszcza, że źródła, jakimi dysponuje, nie odnotowują wieku, a tylko niektóre datę ślubu (intercyzy)? Mimo ciągłego pojawiania się w tekście książki słów „struktura”, „rekonstrukcja struktur rodzinnych”, „typologia” Autorka nie bada struktur w rozumieniu laslettowskim ${ }^{5}$, nie odtwarza żadnych struktur rodzin (u Lasletta jest to gospodarstwo domowe), ani ich nie rekonstruuje. Badać ich nie może, bo nie ma ku temu odpowiednich źródeł, ponieważ takowe po prostu dla tego okresu nie istnieją. Podstawowym źródłem, do którego ma zastosowanie typologia P. Lasletta jest imienny spis ludności, a w wypadku metody L. Henry’ego księgi metrykalne.

Następnie na stronach 12-14 omówione zostały podstawowe pojęcia dla rekonstrukcji struktur rodzinnych (filiacja, koicja, pokrewieństwo, powinowactwo, swojactwo, bliskość) oraz rozpisane stopnie pokrewieństwa. Autorka wypisuje nazewnictwo pokrewieństwa i bliskości oraz określa, co znaczą. Są to jednak pojęcia związane z genealogią, a nie z rekonstrukcją opartą na założeniach L. Henry'ego.

W rozdziale drugim zatytułowanym „Analiza aktowej dokumentacji pod kątem rekonstrukcji rodzin" (s. 15-32) Autorka omawia dokumentację prawno-majątkową, która zawiera w sobie rodzinną i swojacką terminologię, czyli, jak pisze, informacje niezbędne dla rekonstrukcji rodzinnych struktur. Wskazuje tu

4 Linia Hajnala to umowna granica ciągnąca się wzdłuż linii pomiędzy Sankt Petersburgiem i Triestem. W 1965 r. John Hajnal zaproponował umowny podział Europy na dwa obszary charakteryzujące się różnym wiekiem zawierania małżeństw. Na zachód od tej linii małżeństwa zawierano w późnym wieku, co przekładało się na niższą liczbę potomstwa. Obszar ten charakteryzował się również wysokim odsetkiem osób bezżennych. Obszary na wschód od tej linii charakteryzowało wcześnie zawierane małżeństwa, wysoka dzietność i znikomy odsetek osób bezżennych, tamże, s. 278.

5 Podstawą klasyfikacji w typologii Petera Lasletta jest gospodarstwo pary małżeńskiej (Laslett zakładał również istnienie gospodarstw nierodzinnych i osób samotnych), które w zależności od występowania dzieci i różnej kategorii krewnych, służby domowej i komorników było klasyfikowane do różnych typów gospodarstw, tamże, s. 149 i n. 
na akta kupna-sprzedaży nieruchomości, podziału spadków, wydzielenia majątków dla synów i posagów dla córek, kontrakty ślubne, zapisy dożywocia, zapisy darowizn itp., które mogą zawierać wskazówki, co do rodzinnego związku poszczególnych osób oraz rodzinną terminologię.

$\mathrm{Na}$ kolejnych pięćdziesięciu stronach (s. 33-85), w rozdziale zatytułowanym „Aktowa terminologia rodzinna” Autorka omawia terminy określające pokrewieństwo występujące w aktach prawno-majątkowych spisanych na kartach ksiąg grodzkich i ziemskich. Omawia każdy z terminów, pokazuje ich różne wersje językowe, synonimy i przykłady użycia. Są to terminy stopnia pokrewieństwa w linii prostej, terminy bocznej linii pokrewieństwa terminy niepewnego pokrewieństwa, terminy swojactwa (powinowactwa), terminy rodzinne ogólnego charakteru. Zebrany przez I. Woronczuk obszerny i poparty licznymi przykładami materiał terminologiczny jest ważnym dokonaniem w znacznym stopniu wzbogacającym dorobek ukraińskiej, ale i polskiej nauki w tym zakresie.

W podrozdziale „Etapy badań nad pochodzeniem rodowym” (s. 85-103) Autorka przedstawia metody badań i rekonstrukcji wołyńskich rodów szlacheckich, które określa jako komparatywne, historyczno-rekontrukcyjne i historyczo-typologiczne. Chodzi tu o analizę porównawczą materiału, dzięki któremu udało się zrekonstruować rodowody poszczególnych rodów szlacheckich i ustalić powiązania krewniacze z innymi rodami. Zwraca przy tym uwagę na częste problemy, z jakimi boryka się historyk przy rekonstrukcji rodów: częsty brak wskazówek, co do filiacji wewnątrz rodziny, np. te same imiona osób mieszkających w tych samych majątkach i najczęstszy problem w genealogii, czyli połączenie dwóch osób w jedną lub rozdzielenie jednej na dwie, posługiwanie się przez wiele z rodzin antroponimami od posiadanych majątków, zapisywanie skróconych oraz różnych wersji imion i nazwisk w dokumentach np. Jan, Janusz, Iwan, Iwaszko, Iwachno, Wanko oraz Ohafia, Ohapka, Anna, Hanna (s. 81).

Autorka uważa, że zastosowane przez nią metody rekonstrukcji rodów umożliwiły jej odtworzenie struktury ówczesnych rodzin i rodowodów wołyńskiej szlachty, co w perspektywie daje możliwość stworzenia na ich podstawie ogólnego modelu ukraińskiej rodziny XVI-XVII w. (s. 83). Twierdzi również, że usystematyzowany materiał i rodowody odtworzone na podstawie strukturalno-typologicznego podejścia pozwalają prześledzić proces powstawania i funkcjonowania rodzinnych struktur, ich osobliwości oraz ewolucji form rodziny, jako społecznego zjawiska w pewnym okresie historycznym oraz, iż uogólnienie danych daje możliwość nie tylko prześledzić kolejność zmian różnych form rodzinnych i ich 
typów w czasie, ale również daje możliwość ustalenia czynników, które wywoływały i napędzały zarówno konserwowanie pewnych form i typów rodzinnych, jak i ich transformację. Zebrany materiał, jej zdaniem, pozwoli również zrozumieć dynamikę rozwoju rodziny. Pisze też, że jest świadoma tego, iż przedstawione rodowe schematy wołyńskiej szlachty nie odtwarzają absolutnie pełnego rodowodu (brak w dokumentach informacji o dorosłych zamężnych córkach, o zmarłych w dzieciństwie, zmarłych dorosłych, gdyż nie było potrzeby ich wymieniać, a dzieci często zapisywano bez zaznaczenia ich liczby, wieku i płci, s. 84).

W podrozdziale tym znajdujemy również zarys historii badań genealogicznych i znaczenia wiedzy genealogicznej wśród społeczeństw antycznych, średniowiecznych i nowożytnych - rodowód ważny zwłaszcza przy zamykaniu się stanu szlacheckiego i konieczności udowadniania odpowiedniego pochodzenia i herbu. Stąd genealogia rozwija się równolegle z heraldyką. Autorka opisuje jak wygląda praca genealoga i wymienia etapy tej pracy: zbieranie materiału na temat osoby/ rodu, formowanie tzw. dossier, a następnie na podstawie zebranych materiałów tworzenie genealogiczną mapę, a na koniec graficzne przedstawienie rodowodów. Omawia czym, jej zdaniem, są te trzy wymienione etapy pracy, jak powinny przebiegać i jakie elementy zawierać (s. 88). Szczególnie dużo miejsca poświęca tworzeniu drzew genealogicznych (s. 92-103).

Kolejny podrozdział pt. „Procedura rekonstrukcji struktur rodzinnych (na przykładzie rodowodu kniaziów Rużyńskich)” składa się z dwóch części: omówienia stanu ukraińskich badań nad genealogią szlachty wołyńskiej (s. 104-120) oraz z przedstawienia procedury rekonstrukcji struktur rodzinnych (s. 120-134). W pierwszej części bardzo obszernie omawia polskie herbarze w układzie chronologicznym, począwszy od Herbów Rycerstwa Polskiego Bartosza Paprockiego, na Józefie Wolffie, Wiktorze Wittygu i Kazimierzu Pułaskim kończąc. W drugiej części przedstawia rekonstrukcję rodu kniaziów Rużyńskich obszernie omawiając treść i jej znaczenie dla rekonstrukcji rodów różnego rodzaju źródeł dotyczących poszczególnych członków rodziny.

Na kolejnych stronach (s. 138-175) odnajdujemy edycję 14 dokumentów, w większości o charakterze prawno-majątkowym, które, jak można się domyśleć, mają zobrazować bogactwo treści i informacji przydatnych do identyfikacji przedstawicieli różnych rodzin. Poprzedza je trzystronicowe omówienie zasad wydawniczych (s. 135-137).

Zwieńczeniem książki są „Tablice rodowodowe wołyńskiej szlachty XVI pierwszej połowy XVII w. (rekonstrukcja na podstawie wołyńskich ksiąg akto- 
wych)" zajmujące przeszło sto stron (s. 176-307). Autorka zamieściła 145 tablic-drzew z danymi genealogicznymi dotyczącymi 70 rodów wołyńskich. Poprzedza je kilka zdań na temat zasad ich przygotowania oraz wykaz wykorzystanych skrótów. Tablice są niezwykle cennym materiałem zawierającym szereg informacji publikowanych najczęściej po raz pierwszy. Brakuje tu jednak wyjaśnienia, dlaczego właśnie te, a nie inne rody zostały wybrane dla publikacji oraz choćby krótkiej noty na ich temat. Dysponując tak obszernym materiałem prawno-majątkowym Autorka z łatwością mogła przedstawić informacje o dobrach posiadanych przez konkretne rodziny, co pozwoliłoby ocenić zamożność, a przez to znaczenie rodu.

W nagłówkach tablic znajduje się nazwisko rodu, jego herb oraz wymieniona została najważniejsza, dla danego rodu, podstawa źródłowa. Są one numerowane od 1 do 70 z dodaniem litery, gdy jednego rodu dotyczy więcej niż jedna tablica. W wypadku numeracji niezrozumiałe jest dodanie na początku każdego numeru rzymskiej cyfry „I”, która nie ma żadnego uzasadnienia i nie odnajdujemy w publikacji wyjaśnienia, czemu służy taki zapis.

W tablicach odnajdujemy imiona i imiona odojcowskie, informacje o współmałżonkach, pełniony urząd i przy niektórych postaciach datę śmierci, często tylko przybliżoną. Przy wielu tablicach brak jest jakiejkolwiek daty, co znacznie utrudnia ich wykorzystanie. Można było załączyć chociażby informację o terminie zawarcia związku małżeńskiego przez poszczególne pary, zwłaszcza, że takie informacje znajdują się w intercyzach ślubnych i zapisach wzajemnego dożywocia. Przy czym wydaje się zbędnym powtarzający się przy każdej osobie zapis o nieznanym współmałżonku, zwłaszcza, że nie wiadomo czy osoby te w ogóle zawarły związek małżeński. Tablice są czytelne i przejrzyste.

Za tablicami znajduje się ukraińsko-łaciński słownik rodzinnej terminologii (s. 308-309) oraz indeksy geograficzny (s. 310-314) i osobowy (s. 315-509). Indeks osobowy jest właściwie obszernym słownikiem biograficznym osób wymienionych w tablicach genealogicznych, który niczego nowego nie wnosi do wiedzy na ich temat. Autorka na prawie dwustu stronach powiela informacje $\mathrm{z}$ tablic.

Przedstawiona powyżej książka pt. Rodowody szlachty wołyńskiej XVI-pierwszej połowy XVII $w$. wnosi wiele cennych informacji na temat szlachty wołyńskiej zaznaczonego w tytule okresu. Znacznie poszerza naszą dotychczasową wiedzę o genealogii poszczególnych rodzin oraz o więzach pokrewieństwa pomiędzy poszczególnymi rodami szlacheckimi. Całość zebranego materiału przedstawiona $\mathrm{w}$ tablicach genealogicznych i indeksie osobowym została zaprezentowana w sposób przejrzysty i łatwy do odczytania. 
Wartością książki jest również obszerny i poparty licznymi przykładami materiał terminologii określającej relacje krewniacze i powinowactwa. Zebranie jej i omówienie w jednym miejscu w znacznym stopniu wzbogacają dorobek ukraińskiej, ale i polskiej nauki w tym zakresie.

Docenić należy również ideę I. Woronczuk, której celem było odnalezienie źródeł pochodzących z przełomu XVI i XVII w. mogących stanowić podstawę do badań nad strukturą rodziny tego okresu, typologią i jej przeobrażeń w czasie i pod wpływem kataklizmów politycznych dotykających Wołyń w czasach nowożytnych, z wykorzystaniem metod demograficznych Louisa Henry'ego i Petera Lasletta. Niestety, jest to słabsza część książki. Akta o charakterze prawno-majątkowym zawierają informacje o relacjach rodzinnych, ale są one zbyt skromne i zbyt jednostkowe, by mogły zostać uznane za źródła masowe w takim stopniu jak księgi metrykalne i imienne spisy ludności, będące podstawą badań demograficznych. Są jednak doskonałym materiałem do rekonstrukcji rodzin o charakterze genealogicznym, co autorka wykonała doskonale.

Dr Konrad Rzemieniecki, Zakład Narodowy im. Ossolińskich ul. Szewska 37, 50-139 Wrocław rzemieniecki@interia.pl 